\title{
Komunikasi Dokter dengan Sikap Konkordansi pada Pasien Tuberkulosis Paru, Hipertensi, dan Asma
}

\section{Concordance Attitude of Doctors Communication Toward the Patient of Lung Tuberculosis, Hipertention, and Asthma}

\author{
Ita Patriani* Dumilah Ayuningtyas**
}

\author{
*Rumah Sakit Umum Daerah Mataram Nusa Tenggara Barat, **Departemen Administrasi dan Kebijakan \\ Kesehatan Fakultas Kesehatan Masyarakat Universitas Indonesia
}

\begin{abstract}
Abstrak
Pengobatan penyakit kronik tidak hanya membutuhkan ketersediaan obat dan petugas kesehatan yaitu dokter, tetapi juga tiga faktor yakni kepatuhan (compliance), aderensi (adherency), dan konkordansi (concordance). Ketiga faktor tersebut sangat penting dalam upaya penanganan penyakit kronik, termasuk tuberkulosis (TB) paru, hipertensi, dan asma. Untuk mewujudkan sikap konkordansi, dibutuhkan komunikasi efektif antara dokter dan pasien. Komunikasi yang terjalin efektif akan meningkatkan pemahaman dan motivasi dalam diri pasien untuk mengikuti nasihat dari dokter. Adapun penelitian ini dilatarbelakangi oleh tingginya angka penderita dan angka kegagalan berobat (drop out) pasien tuberkulosis paru, hipertensi, asma di Rumah Sakit Umum Daerah Kota Mataram. Penelitian ini bertujuan untuk melihat hubungan komunikasi dokter dan karakteristik pasien dengan sikap konkordansi pasien. Penelitian dengan desain studi potong lintang ini dilakukan terhadap 174 pasien TB paru, hipertensi, dan asma sebagai responden. Hasil penelitian ini menunjukkan bahwa pendidikan, pengeluaran, dan komunikasi merupakan variabel yang berhubungan dengan sikap konkordansi pada pasien TB paru, hipertensi, dan asma. Rekomedasi tindak lanjut dari penelitian ini adalah peningkatan fasilitas ruangan untuk meningkatkan kenyamanan komunikasi pasien dan dokter, penyelenggaraan program pengembangan kemampuan komunikasi dokter, dan survei berkala untuk menilai proses komunikasi dokter-pasien.

Kata kunci: Asma, hipertensi, komunikasi dokter, sikap konkordansi, tuberkulosis paru
\end{abstract}

\section{Abstract}

The therapy of chronic diseases is not only needed drugs supply and health staff, that is physician, but also three factors such as compliance, adherence, and concordance. The three of factors are crucial in the handling of chronic diseases like lung tuberculosis, hypertension, and asthma. To accomplish a concordance attitude is needed an effective communication between physician and patient. The effective communication may increase the understanding and motivation of patients to comply the physician's advice. The research is based on the high prevalence rate and drop out rate of the patients of lung tuberculosis, hypertension, and asthma at Mataram City General Hospital. This research is proposed to show the association of the effectiveness of physician communication and characteristics of patients to the concordance attitude of patients. Cross sectional design was employed in this study with 174 patients of lung tuberculosis, hypertension, and asthma as respondents. The results of this study indicate that education, expenditures, and communication are variables related to concordance in TB, hypertension and asthma patients. It is recommended to maintain room facilities so that patient and doctor feel comfortable to communicate and to conduct a doctor communication skill development program as well as a regular survey of patient-doctor communication process.

Keywords: Asthma, hypertension, doctor communication, concordance attitude, lung tuberculosis

\section{Pendahuluan}

Lebih dari satu abad yang lalu, Mycrobacterium penyebab penyakit tuberkulosis (TB) ditemukan, tetapi hingga kini penyakit tersebut tetap menjadi masalah kesehatan di berbagai negara di dunia termasuk Indonesia. Pada tahun 2011, sekitar 8,7 juta penduduk dilaporkan terinfeksi TB dan 1,4 juta berakhir dengan kematian. Lebih dari 95\% kematian di negara berkembang dan miskin disebabkan oleh TB yang menjadi penyebab satu dari tiga kematian wanita berusia 15 hingga 44 tahun. ${ }^{1}$

Dalam upaya menurunkan prevalensi dan insiden

Alamat Korespondensi: Dumilah Ayuningtyas, Departemen Administrasi dan Kebijakan Kesehatan FKM Universitas Indonesia, Kampus Baru UI Gd. F Lt.1 Depok 16424, Hp.08161840446,e-mail:dumilah@gmail.com 
penyakit tuberkulosis, hipertensi, dan asma, banyak hambatan yang menyebabkan kegagalan upaya pemberantasan. Untuk dapat berhasil baik, upaya penyembuhan penyakit-penyakit tersebut memerlukan kerja sama pasien dan dokter. Berbagai faktor yang menjadi alasan penderita untuk tidak berobat teratur adalah jarak fasilitas pelayanan kesehatan, kesibukan kerja, biaya transportasi mahal. Alasan lain meliputi pasien merasa sembuh, pelayanan petugas tidak memuaskan serta pemahaman pengobatan rendah. Pengobatan yang kurang optimal dapat disebabkan oleh faktor pasien, faktor pelayanan kesehatan dan faktor petugas kesehatan. Keberhasilan pengobatan memerlukan ketersediaan obat, ketulusan petugas kesehatan, dan kepatuhan pasien berobat secara teratur. ${ }^{2}$ Indikator kepatuhan (compliance), aderensi (adherency) dan konkordansi (concordane) sering dinilai dalam penatalaksanaan berbagai penyakit kronik. Kepatuhan adalah tingkah laku pasien untuk mengikuti segala saran petugas kesehatan. Aderensi adalah komitmen pasien terhadap pengobatan yang telah ditentukan. Konkordansi adalah bentuk kerjasama antara dokter dan pasien dalam melakukan tindakan pengobatan. ${ }^{3}$

Jumlah penderita penyakit TB paru, hipertensi, dan asma di Rumah Sakit Umum Daerah (RSUD) Kota Mataram tergolong tinggi. Dalam periode Januari hingga September 2011, jumlah pasien rawat inap dan rawat jalan meliputi TB paru 74 kasus, hipertensi 417 kasus, dan asma 69 kasus, tetapi jumlah penderita putus berobat menurut dokter yang merawat jumlah tersebut tergolong tinggi. Tanpa penanganan penderita putus berobat secara baik, dapat dipastikan akan terjadi berbagai dampak yang tidak diinginkan seperti resistensi obat, komplikasi dan kematian. Proses penyembuhan dan pengendalian penyakit sangat membutuhkan konkordansi antara lain komunikasi dokter dengan pasien. Komunikasi yang efektif antara dokter dan pasien dapat meningkatkan sikap konkordansi pasien TB paru, hipertensi, dan asma. Penelitian bertujuan mengetahui hubungan antara komunikasi dan berbagai faktor individu pasien yang berhubungan dengan sikap konkordansi.

\section{Metode}

Penelitian kuantitatif dengan desain studi potong lintang ini dilaksanakan di klinik penyakit dalam dan ruang rawat inap RSUD Kota Mataram pada periode Desember 2011 - Februari 2012. Populasi penelitian ini adalah semua pasien penderita TB paru, hipertensi, dan asma yang berumur lebih dari 18 tahun. Sampel dalam penelitian ini adalah sebagian dari pasien di rumah sakit pada saat penelitian dilakukan, dengan kriteria inklusi meliputi pasien rawat jalan/inap rumah sakit yang telah berobat dua kali, berusia kurang dari 18 tahun, dan berdomisili di Mataram berjumlah 174 penderita.

Variabel yang diteliti meliputi variabel dependen sikap konkordansi dan variabel independen karakteristik pasien yang meliputi usia, jenis kelamin, pendidikan, pekerjaan, pengeluaran, dan sumber pembiayaan. Sementara aspek komunikasi efektif dokter yang dinilai meliputi keterbukaan, empati, sikap positif mendukung, dan sikap positif. Nilai ketiga aspek tersebut disatukan menjadi satu nilai keefektifan komunikasi. Variabel yang dianalisis meliputi sikap terhadap konkordansi, komunikasi efektif, keterbukaan, empati, dan sikap mendukung. Semua variabel tersebut diukur dalam skala numerik. Analisis dilakukan adalah analisis bivariat uji korelasi dan regresi liner sederhana. Uji korelasi digunakan untuk mengetahui derajat atau keeratan hubungan dua variabel numerik.

\section{Hasil}

Sikap konkordansi pasien TB paru, hipertensi, dan asma dengan dokter di RSUD Kota Mataram terhadap pengobatan masih tergolong rendah. Variabel jenis kelamin tidak berhubungan signifikan dengan sikap konkordansi pasien TB paru, hipertensi, dan asma. Variabel pendidikan berhubungan signifikan dengan sikap konkordansi pasien TB paru, hipertensi, dan asma. Artinya, semakin tinggi pendidikan seseorang, akan semakin baik sikap konkordasinya. Terdapat hubungan signifikan antara pengeluaran responden dan komunikasi dengan sikap konkordansi/kepatuhan pasien TB paru, hipertensi, dan asma untuk berobat. Berdasarkan cara pembayaran, pasien TB paru, hipertensi, dan asma menunjukkan jumlah yang lebih banyak pada responden yang bersikap tidak konkordansi. Analisis bivariat memperlihatkan hubungan yang tidak signifikan antara cara pembayaran pengobatan responden dengan sikap konkordansi dengan nilai $p=0,963$. Analisis univariat terhadap penilaian variabel komunikasi efektif dilakukan dengan tiga kategori meliputi keterbukaan, empati, dan sikap mendukung. Sebagian besar responden menyatakan komunikasi dengan dokter kurang efektif. Komunikasi yang efektif mengarah pada sikap konkordansi yang berhubungan siginifikasi dengan nilai $\mathrm{p}=0,000$. Dapat disimpulkan bahwa ada hubungan yang signifikan antara komunikasi dokter pasien dan sikap konkordansi (Tabel 1).

Pada uji multivariat, ditemukan variabel yang memengaruhi sikap konkordansi pasien TB paru, hipertensi, dan asma di RSUD Kota Mataram yang antara lain adalah variabel tingkat pendidikan responden, pengeluaran per bulan responden, keterbukaan, dan sikap mendukung. Variabel yang paling memengaruhi sikap konkordansi pasien adalah keterbukaan, peningkatan keterbukaan antara dokter-pasien menaikkan skor konkordansi (Tabel 2). 
Tabel 1. Distribusi Pasien TB Paru, Hipertensi, dan Asma Menurut Jenis Kelamin dan Hubungan dengan Sikap Konkordansi

\begin{tabular}{|c|c|c|c|c|c|c|c|c|}
\hline \multirow{3}{*}{ Variabel Independen } & \multirow{3}{*}{ Kategori } & \multicolumn{6}{|c|}{ Konkordansi } & \multirow{3}{*}{ Nilai $p$} \\
\hline & & \multicolumn{2}{|c|}{ Tidak } & \multicolumn{2}{|c|}{ Ya } & \multicolumn{2}{|c|}{ Total } & \\
\hline & & $\mathbf{n}$ & $\%$ & $\mathbf{n}$ & $\%$ & $\mathbf{n}$ & $\%$ & \\
\hline \multirow[t]{2}{*}{ Jenis Kelamin } & Laki-laki & 48 & 58,5 & 34 & 41,5 & 82 & 100 & 0,145 \\
\hline & Perempuan & 68 & 70,1 & 29 & 29,9 & 97 & 100 & \\
\hline \multirow[t]{2}{*}{ Pendidikan } & $\leq$ SLTA & 85 & 75,9 & 27 & 24,1 & 112 & 100 & 0,000 \\
\hline & $>$ SLTA & 31 & 47,0 & 35 & 53,0 & 66 & 100 & \\
\hline \multirow[t]{2}{*}{ Pengeluaran } & $\leq 2$ juta & 77 & 74,8 & 26 & 25,2 & 103 & 100 & 0,000 \\
\hline & $>2$ juta & 20 & 35,7 & 36 & 64,3 & 56 & 100 & \\
\hline \multirow[t]{2}{*}{ Cara bayar } & Pribadi & 22 & 66,7 & 11 & 33,3 & 33 & 100 & 0,963 \\
\hline & Pihak ketiga & 94 & 64,4 & 52 & 35,6 & 146 & 100 & \\
\hline \multirow[t]{2}{*}{ Komunikasi } & Efektif & 15 & 24,2 & 47 & 75,8 & 62 & 100 & 0,000 \\
\hline & Kurang efektif & 101 & 86,3 & 16 & 13,7 & 117 & 100 & \\
\hline
\end{tabular}

Tabel 2. Analisis Multivariat

\begin{tabular}{lll}
\hline Variabel & B & Nilai p \\
\hline Usia & 0,010 & 0,454 \\
Jenis kelamin & $-0,272$ & 0,395 \\
Tingkat pendidikan & 0,335 & 0,011 \\
Pekerjaan & 0,027 & 0,606 \\
Pengeluaran per bulan & $-3,622 \mathrm{E}-7$ & 0,035 \\
Cara pembayaran & 0,049 & 0,826 \\
Komunikasi & 0,366 & 0,000 \\
\hline
\end{tabular}

\section{Pembahasan}

Sikap konkordansi pasien TB paru, hipertensi, dan asma dengan dokter di RSUD Kota Mataram terhadap pengobatan masih rendah. Sekitar $75,8 \%$ pasien memiliki persepsi bahwa terdapat komunikasi efektif antara dokter-pasien dan mempunyai sikap yang konkordansi terhadap pengobatan. Sedangkan, di antara pasien yang menilai komunikasi dokter-pasien kurang efektif, sekitar $86,3 \%$ bersikap tidak konkordansi terhadap pengobatan. Hal tersebut disebabkan oleh proses pengobatan yang membutuhkan waktu yang lama dan konsisten untuk melakukan kunjungan ulang secara teratur. Pasien cenderung bosan dan lupa untuk mematuhi anjuran pengobatan sehingga dibutuhkan kedisiplinan untuk menjalankan pengobatan yang tuntas.

Penelitian mahasiswa kedokteran Leeds University School of Medicine, ${ }^{4}$ terhadap pasien hipertensi, memperlihatkan tingkat respons yang tinggi, pada tahun pertama sebanyak $92,5 \%$, tahun kedua ketika mulai sebanyak $80 \%$ dan tahun kedua pada akhir sebanyak $84,5 \%$. Penelitian lainnya yang menggunakan data sekunder rekam medik dan wawancara 40 orang pasien berobat jalan di California mendapatkan hasil konkordansi meliputi keluhan utama, mengerti tentang diagnosis penyakit, obat-obatan dan rencana pengobatan adalah sangat baik. ${ }^{5}$ Konkordansi hanya terjadi apabila pada saat konsultasi, pasien dan dokter berada dalam keadaan yang harmonis. ${ }^{2}$ Upaya menjaga dan meningkatkan konkordansi sebagai bagian dari manajemen penyakit mencakup semua aspek termasuk gender, etnik, usia, keluhan, obat-obatan, kepuasan, serta akurasi rekam medik. $^{3}$

Tidak terdapat hubungan yang signifikan antara jenis kelamin dengan sikap konkordansi pasien TB paru, hipertensi, dan asma. Tidak ada perbedaan laki-laki dan perempuan dalam sikap konkordansi. Laki-laki atau perempuan dapat memiliki sikap konkordansi yang lebih. Pada penelitian ini, proporsi responden laki-laki dan perempuan hampir seimbang. Lebih dari separuh responden baik laki-laki dan perempuan tidak memiliki sikap konkordansi. Variabel jenis kelamin memengaruhi perilaku kesehatan yang merupakan refleksi berbagai gejala yang memengaruhi variabel lain, seperti pengetahuan, keinginan, kehendak, minat, motivasi, persepsi, sikap dan sebagainya. 6,7

Tidak terdapat hubungan yang signifikan antara umur dengan sikap konkordansi. Artinya, seseorang yang memiliki umur lebih muda dapat memiliki sikap konkordansi yang baik dibandingkan yang lebih tua atau sebaliknya. Usia memengaruhi sikap dan perilaku kesehatan seseorang melalui pengambilan keputusan. Artinya, semakin tua seseorang, semakin banyak pengalaman dan informasi yang dimiliki termasuk informasi ataupun pengetahuan tentang kesehatan yang menjadi dasar dalam pengambilan keputusan proses pengobatan. ${ }^{6}$ Pada penelitian ini, usia tidak berpengaruh terhadap sikap konkordansi pasien dalam menjalani proses pengobatan yang membutuhkan kedisiplinan.

Tingkat pendidikan berhubungan bermakna dengan sikap konkordansi pasien TB paru, hipertensi, dan asma, semakin tinggi pendidikan semakin baik sikap konkordansi. Sebagian besar tingkat pendidikan responden adalah di bawah dan setara SLTA. Tingkat pendidikan memengaruhi daya nalar seseorang sehingga dan daya 
nalar yang baik memudahkan mereka untuk meningkatkan pengetahuan sehingga termotivasi meningkatkan konkordansi dalam pengobatan. Tingkat pendidikan yang lebih tinggi cenderung mempunyai perilaku kesehatan yang baik seperti mematuhi pengobatan yang dianjurkan. Pada penelitian ini, sebagian besar responden dengan tingkat pendidikan di bawah dan setara SLTA bersikap konkordansi daripada tingkat pendidikan di atas SLTA. Namun, kejenuhan menjalani proses pengobatan mungkin saja berpengaruh dalam sikap konkordansi. ${ }^{4-6}$

Tidak terdapat hubungan yang bermakna antara pekerjaan dengan sikap konkordansi atau jenis pekerjaan. Sebagian besar responden yang berobat mempunyai pekerjaan formal tidak memiliki sikap konkordansi. Responden yang bekerja cenderung tidak patuh berobat karena mereka tidak memiliki waktu yang cukup, tetapi dapat juga mempunyai pengertian bahwa pekerjaan tidak menghalangi mereka untuk berobat. ${ }^{4,5}$ Selain itu, variabel demografi seperti ciri individu juga digunakan untuk memprediksikan kepatuhan berobat.

Penelitian ini menemukan hubungan signifikan antara pengeluaran responden dengan sikap konkordansi. Pengeluaran setiap bulan yang semakin besar membuat responden bersikap konkordansi pada penyakit. Salah satu faktor yang memengaruhi masyarakat untuk datang kembali berobat atau memanfaatkan pelayanan kesehatan adalah penghasilan. ${ }^{8}$ Pengeluaran seseorang berhubungan erat dengan penghasilan yang dia dapatkan setiap bulan. Apabila kemampuan memenuhi kebutuhan telah seimbang dengan pengeluaran bahkan lebih, maka keinginan melakukan kontrol berobat akan timbul. Namun, apabila pengeluaran lebih banyak daripada penghasilan yang didapat, maka kemungkinan seseorang kembali melakukan pengobatan yang teratur menjadi lebih kecil.

Tidak terdapat hubungan yang signifikan antara cara pembayaran pengobatan dengan sikap konkordansi. Sebagian besar responden melakukan pembayaran melalui pihak ketiga, Askes, Jamkesmas/Jamkesda, dan jaminan dari perusahaan sehingga tidak terbebani biaya pengobatan. Dengan jaminan pihak ketiga dalam mengatasi biaya rumah sakit diharapkan pasien tidak lagi mempertimbangkan masalah biaya kesehatan. Keikutsertaan dalam asuransi merupakan salah satu faktor pendukung dalam perilaku kesehatan, bahwa pembayaran dari pihak ketiga berperan dalam pemanfaatan fasilitas kesehatan. $8,10,11$ Jaminan pembayaran dari pihak ketiga dapat mendorong seseorang untuk terus melakukan proses pengobatan. Namun, pada penelitian ini variabel jaminan dari pihak ketiga tidak membuat pasien bersikap konkordansi. Sebagian besar responden dengan pembayaran pihak ketiga tidak bersikap konkordansi, mungkin karena tidak mengeluarkan biaya berobat justru mem- buat pasien tidak patuh berobat.

Terdapat hubungan komunikasi efektif dokter-pasien dengan konkordansi/kepatuhan pasien TB paru, hipertensi, dan asma untuk berobat. Hasil univariat terhadap penilaian variabel komunikasi efektif dilihat melalui tiga kategori meliputi keterbukaan, empati, dan sikap mendukung. Sebagian besar responden menyatakan komunikasi dilakukan oleh dokter dengan pasien TB paru, hipertensi, dan asma di RSUD Kota Mataram kurang efektif.

Komunikasi efektif tersebut dapat terlihat dari unsur keterbukaan dokter yang dirasakan oleh pasien sehingga dapat menimbulkan rasa percaya dan pasien berkata jujur tentang hal yang dirasakan. Hal tersebut membuat informasi atas rasa sakit yang dialami oleh pasien dapat dikomunikasikan dengan baik. Untuk mencapai tujuan komunikasi, penerima informasi dapat mengetahui sesuatu yang dia inginkan.9,10,12 Selain itu, unsur empati dan simpati turut menyusun komunikasi efektif. Rasa empati yang timbul dan ditunjukkan oleh dokter kepada pasien membuat pasien mau memahami penjelasan dan saran dari dokter. Rasa simpati dapat muncul karena penggunaan bahasa yang mudah dimengerti. Dengan sikap dokter yang mendukung, pasien merasa mendapat motivasi untuk melakukan saran-saran yang diberikan.

Uji multivariat mendapatkan variabel yang memengaruhi sikap konkordansi pasien TB paru, hipertensi, dan asma adalah tingkat pendidikan, pengeluaran per bulan, keterbukaan, dan sikap mendukung. Variabel yang paling dominan memengaruhi sikap konkordansi pasien adalah keterbukaan, dengan peningkatan keterbukaan antara dokter-pasien skor konkordansi meningkat. Tiga aspek yang harus diketahui oleh komunikator yang menyangkut khalayak meliputi sosiodemografi, profil psikologis dan karakteristik perilaku khalayak. Seseorang bersedia menerima informasi bukan hanya karena isi pesan, tetapi juga oleh semua komponen yang mendukung proses komunikasi. $^{2}$

Keterbukaan antara dokter-pasien dapat meningkatkan kepercayaan tentang proses pengobatan yang akan dan sedang dilakukan. RSUD Kota Mataram mempunyai dokter yang berpengalaman menangani pasien dari berbagai latar belakang sosioekonomi, sehingga dokter mampu berkomunikasi dengan baik dan dapat diterima oleh pasien. Pendapat dan saran yang diberikan oleh dokter dapat diterima oleh pasien karena sikap terbuka dan mendukung dokter menghadapi dan mengobati penyakit yang diderita pasien yang menciptakan sikap konkordansi pasien. Selain itu, dokter harus mampu menjelaskan dengan baik kondisi pasien dengan bahasa yang mudah dimengerti, menjelaskan manfaat pengobatan, menasihati yang harus dilakukan selama pengobatan sehingga pasien berterus terang, percaya, merasa nyaman untuk 
menceritakan keluhan kepada dokter, dan menimbulkan sikap konkordansi pasien yang baik. Sikap konkordasi dokter-pasien dapat terjalin dengan baik apabila komunikasi telah berjalan dengan baik sehingga tujuan pengobatan dapat tercapai. ${ }^{2}$

\section{Kesimpulan}

Sebagian besar pasien penderita TB paru, hipertensi, dan asma di RSUD Kota Mataram bersikap yang tidak konkordansi. Karakteristik individu yang berhubungan dengan sikap konkordansi adalah pendidikan dan pengeluaran responden. Sementara, jenis kelamin, usia, pekerjaan, dan cara pembayaran responden tidak memiliki hubungan dengan sikap konkordansi. Selain itu, terdapat hubungan yang signifikan antara komunikasi yang efektif dengan sikap konkordansi pasien. Pasien TB paru, hipertensi, dan asma yang berpersepsi bahwa komunikasi antara pasien dan dokter berjalan efektif cenderung bersikap konkordansi.

\section{Saran}

Perlu dilakukan pemberitahuan secara berkala kepada para dokter bahwa komunikasi yang efektif pada pasien berpengaruh pada proses pengobatan dan penyembuhan penyakit. Untuk itu, perlu dilakukan peningkatan fasilitas ruangan sehingga pasien dan dokter merasa nyaman berkomunikasi. Perlu menyelenggarakan program pengembangan kemampuan berkomunikasi dokter sehingga informasi yang disampaikan dapat diterima dengan baik oleh pasien. Komunikasi efektif secara terus menerus mampu menjelaskan kondisi pasien, manfaat pengobatan, nasihat selama pengobatan, membuat pasien berterus terang, percaya, merasa nyaman dapat menimbulkan sikap konkordansi pasien yang baik. Perlu penelitian kualitatif terhadap dokter karena sikap konkordansi tidak ditentukan oleh pasien tetapi juga oleh tenaga kesehatan. Penelitian yang jarang dilakukan itu diharapkan dapat menghasilkan keragaman sikap konkordansi.

\section{Daftar Pustaka}

1. Benson J. Concordance, an alternative term to 'compliance' in the Aboriginal population. Australian Family Physician. 2005; 34(10): 8314

2. Cangara H. Pengantar ilmu komunikasi. Jakarta: Rajawali Pers; 2006.

3. Cushing A, Metcalf R. Optimizing medicines management: from compliance to concordance. International Journal of Therapeutics and Clinical Risk Management. 2007; 3(6):1047-58.

4. Tisnado DM, Adams JL, Liu HH, Damberg CL, Hu FA, Chen WP, et al. Does the concordance between medical records and patient self-report vary with patient characteristics? International Journal Health Services Outcomes Research Methodology. 2006; 6(3-4): 157-75.

5. Eng E and Blanchard L. Action-oriented community diagnosis: a health education tool. International Quarterly of Community Health Education. 2006/2007; 26(2): 141-58

6. Notoatmodjo, Soekidjo. Ilmu kesehatan masyarakat: prinsip-prinsip dasar. Jakarta: Rineka Cipta; 2009.

7. Liliweri A. Dasar-dasar komunikasi kesehatan. Cetakan ke-3 Yogyakarta: Pustaka Pelajar Offset; 2009.

8. Fieldstein. Health care economic. 7th ed. California: Delmar Publisher Inc; 2006.

9. Metcalfe R. Compliance, adherence, concordance - what's in a name?. Practical Neurology. 2005; 5: 192-3.

10. Peterson, Andrew M. Development of a methodology to use the national ambulatory medical care survey and the medical expenditure panel survet concurrently: The Case of Initial Medication Compliance [disertasi]. Philadelphia: Partial Fulfillment of the Requirements of the Degree of Doctor of Philosophy; 2009.

11. Prayoga GLPR. Faktor-faktor yang memengaruhi pilihan pasien rawat jalan RS Risa Medica Mataram terhadap pemilihan tempat bersalin [tesis]. Depok: Fakultas Kesehatan Masyarakat Universitas Indonesia; 2012.

12. Thistlethwaite JE, Raynor DK, Knapp P. Medical students'attitudes toward concordance in medicine taking: exploring the impact of an educational intervention. Education for Health. 2003; 16 (3): 307-17. 